2. Bishara SE. Mandibular changes in persons with untreated and treated Class II division 1 malocclusion. Am J Orthod Dentofacial Orthop. $1998 ; 113(6): 661-673$. 5406(98)70227-6

3. Hayashida H, Ioi H, Nakata S, Takahashi I, Counts AL. Effects of retraction of anterior teeth and initial soft tissue variables on lip changes in Japanese adults. The European Journal of Orthodontics. 2011;33(4):419-426.

4. Weyrich $\mathbf{C}$, Lisson $\mathbf{J A}$. The effect of premolar extractions on incisor position and soft tissue profile in patients with Class II, Division 1 malocclusion. J Orofac Orthop. 2009;70(2):128138. doi:10.1007/s00056-009-0813-2

5. Fitzgerald JP, Nanda RS, Currier GF. An evaluation of the nasolabial angle and the relative inclinations of the nose and upper lip. American Journal of Orthodontics and Dentofacial Orthopedics. 1992;102(4):328-334.

6. Ramos AL, Sakima MT, Pinto A dos $S$, Bowman SJ. Upper lip changes correlated to maxillary incisor retraction--a metallic implant study. Angle Orthod. 2005;75(4):499-505. doi:10.1043/0003-

3219(2005)75[499:ULCCTM]2.0.CO;2

7. Burstone $\mathbf{C J}$. Lip posture and its significance in treatment planning. Am J Orthod. 1967;53(4):262284. doi:10.1016/0002-9416(67)90022-x

8. Maetevorakul S, Viteporn S. Factors influencing soft tissue profile changes following orthodontic treatment in patients with Class II Division 1 malocclusion. Prog Orthod. 2016;17:13. doi:10.1186/s40510-016-0125-1

\title{
THỰC HÀNH VỀ DINH DƯỡNG Ở HỌC SINH Có VẤN ĐỀ VỀ RĂNG MIÊNG TẠI TRƯỜ'NG TIỂU HỌC THI TRẤN VŨ THƯ, TỈNH THÁI BÌNH NĂM 2019
}

\author{
Ngô Văn Mạnh¹, Lê Đức Cường1, Phạm Thị Quý
}

\section{TÓM TẮT 18}

Một nghiên cứu cắt ngang thực hiện trên 324 hoc sinh lớp 4 và lớp 5 của Trường tiểu hoc thi trấn Vũ Thư tỉnh Thái Bình nhằm xác định tỷ lệ học sinh có vấn đề răng miêng và đánh giá thực hành về dinh dưỡng ở học sinh mắc bệnh lý răng miệng. Kết quả nghiên cứu cho thấy: Trong số 324 học sinh được điêu tra có 115 học sinh có vấn đề về răng miệng, tỷ lệ học sinh có vấn đề về răng miêng không ăn 3 bữa thường xuyên ở trẻ nam cao hơn trẻ nữ (lần lượt là $59,3 \%$ và $50,0 \%$ ), sự khác biệt không có ý nghĩa thống kê với $p>0,05$. Tỷ lệ bỏ ăn sáng ở 2 giới đều cao với $85,7 \%$. Tỷ lể học sinh nữ có thói quen ăn đồ ngot và uống nước có ga cao hơn nam giới. Tuy nhiên tỷ lệ học sinh nam có thói quen uống đồ tự pha tại tiệm cao hớn trẻ nữ.

Từ khóa: Thực hành, học sinh, dinh dưỡng, bệnh răng miệng.

\section{SUMMARY \\ NUTRITIONAL PRACTICE IN PUPILS WITH DENTAL PROBLEMS AT PRIMARY SCHOOL IN VU THU TOWN, THAI BINH PROVINCE IN 2019}

A cross-sectional study was conducted on 324 4th and 5th grade pupils of Primary School in Vu Thu Town, Thai Binh province to determine the proportion of pupils with dental problems and to assess nutrition practice among these pupils. Results of the study show that: Among 324 pupils were interviewed, there were 115 pupils with dental problems. The percentage

${ }^{1}$ Trường Đại học Y Dược Thái Bình.

²Bênh viên Đa khoa Vũ Thư, Thái Bình

Chịu trách nhiệm chính: Ngô Văn Mạnh

Email: manhsdh@gmail.com

Ngày nhận bài: 6.7.2021

Ngày phản biên khoa hoc: 27.8.2021

Ngày duyệt bài: 8.9.2021 of pupils with dental problems who do not eat 3 regular meals in boys is higher than that in girls (with $59.3 \%$ and $50.0 \%$, respectively), the difference is not statistically significant $(p>0.05)$. The rate of skipping breakfast in both gender are high with $85.7 \%$. The percentage of girls who eating sweet foods and drinking carbonated water frequently is higher than that of boys. However, the percentage of boys who have a habit of drinking homemade drinks at the shop is higher than that of girls.

Keywords: Practice, students, nutrition, dental disease.

\section{I. ĐĂT VẤN ĐỀ}

Dinh dưỡng là một thành phần thiết yếu trong sự tăng trưởng, phát triển và duy trì cuộc sống lành manh của con người [1]. Riêng đối với sự phát triển hệ răng, chế độ dinh dưỡng tốt sẽ cung cấp những dưỡng chất cần thiết cho quá trình cấu tạo nướu và răng của trẻ. Dinh dưỡng và bệnh răng miêng có mối tương quan với nhau [2], khi dinh dưỡng tốt, chăm sóc răng miệng tốt thì sẽ hạn chế các bệnh răng miệng nhưng thiếu dinh dưỡng (thể thiếu cân và thấp còi) có thể khiến môt người bị sâu răng. Thành phần dinh dưỡng của một món ăn, cách tiêu thụ món ăn đó cũng có thể ngăn ngừa hoặc gây ra bệnh cho hàm răng. Ngược laị, tình trang tốt xấu của răng- miêng cũng có ảnh hưởng vào sự dinh dưỡng của cơ thể [3]. Ở nước ta, cùng với sự thay đổi và phát triển về điều kiện kinh tế xã hội trong những năm gần đây là sự gia tăng việc sử dung đường sữa, bánh keo, nước uống có ga nhiều hơn trong khi đó người dân đặc biệt là lứa tuổi học sinh chưa nhận thức đầy đủ về tác hại 
của bệnh răng miệng và cách thực hành dinh dưỡng để có hàm răng khoẻ mạnh. Vì vậy chúng tôi thực hiện nghiên cứu này với mục tiểu: Đánh giá thực hành về dinh dướng ở học sinh có vấn đề về răng miệng ở khối 4, khối 5 trường tiểu học thị trấn Vũ Thư, tỉnh Thái Bình năm 2019.

\section{II. ĐỐI TƯợNG VÀ PHƯƠNG PHÁP NGHIÊN CỨU 2.1. Địa điểm, thời gian, đối tượng nghiên cứu}

- Địa điểm nghiên cứu: được thực hiện tại trường tiểu học thị trấn Vũ Thư, tỉnh Thái Bình.

- Đối tượng nghiên cứu: Các hoc sinh thuộc khối lớp 4 và khối lớp 5 (vì lứa tuổi này các em đã có hiểu biết nhất định về vấn đề dinh dưỡng. Bên cạnh đó các em đã nhận thức rõ được các thức ăn có lợi , các thức ăn có hại và đặc biệt ít có tâm lý sợ hãi khi khám răng hay khi được phỏng vấn. Răng của đối tượng này đã ổn định) đủ tiêu chuẩn tham gia nghiên cứu.

- Thời gian nghiên cứu: Từ tháng 6/2019 đến tháng 3/2020.

\subsection{Phương pháp nghiên cứu}

2.2.1. Thiết kế nghiên cứu. Nghiên cứu được thiết kế theo phương pháp dịch tễ học mô tả thông qua cuộc điêu tra cắt ngang có phân tích.

\subsubsection{Cỡ mẫu và phương pháp chọn mẫu}

a) Cõ̃ mấu: Toàn bộ học sinh khối lớp 4 và lớp 5 của trường sẽ được mời vào nghiên cứu

Trên thực tế có 324 học sinh tham gia vào nghiên cứu.

b) Phương pháp chọn mẫu. Chon toàn bộ học sinh khối lớp 4 và lớp 5 khám để phát hiện các trường hợp có mắc bệnh răng miệng. Loại trừ những học sinh không có mặt trong thời gian nghiên cứu còn lại có 324 học sinh tham gia vào nghiên cứu. Sau khi khám toàn bộ các học sinh khối 4 và khối 5 , chọn toàn bộ các em có mắc bệnh răng miệng để phỏng vấn thực hành về dinh dương.

\subsection{Phương pháp thu thập thông tin:}

Thông tin được thu thập bằng phương pháp phỏng vấn trực tiếp đối tượng thông qua bộ phiếu điều tra. Xây dựng bộ phiếu điều tra phù hợp với mục tiêu nghiển cứu.

\subsection{Một số biến số trong nghiên cứu}

- Trẻ có vấn đề về răng miệng (VĐRM): được đánh giá qua chỉ số lợi GI, chỉ số vệ sinh răng miệng OHI-S.

- Tỷ lệ học sinh ăn thường xuyên 3 bữa/ngày

- Tỷ lể học sinh bỏ bữa và lý do

- Tỷ lể học sinh ăn các đồ ăn nhanh

- Tỷ lể học sinh ăn sáng

- Các loại thực phẩm mà trẻ hay ăn vào bữa sáng

- Thói quen uống nước có ga của học sinh

- Thói quen ăn đồ ngọt của học sinh

2.5. Phương pháp xử lý số liệu. Số liệu thu thập được nhập liệu kép bằng phần mềm EpiData 3.0. Các số liệu sau khi thu thập, được tổng hợp và xử lý bằng phần mềm SPSS 22.0.

Thống kê mô tả được áp dụng để tính toán tỷ lệ \% học sinh có kiến thức về dinh dưỡng và bệnh răng miệng. Chisquare test được sử dụng để tìm hiểu sự khác biệt về tỷ lệ giữa các nhóm với $\alpha=0,05$

\section{KẾT QUẢ NGHIÊN CỨU}

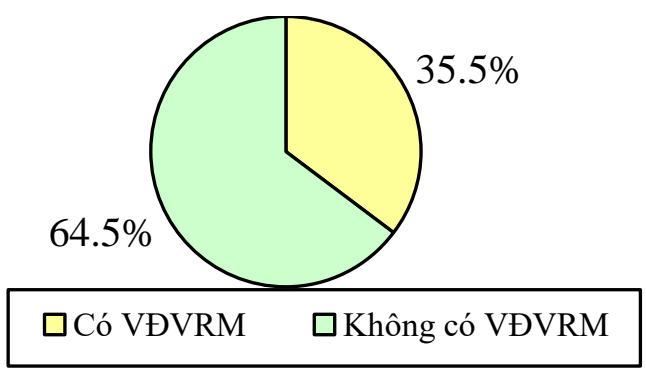

Biểu đồ 1. Tỷ lệ trẻ lớp 4,5 có vấn đề răng miệng Trong số 324 trẻ được khám răng miệng, có 115 trẻ có các vấn đề về răng miệng (chiếm $35,5 \%)$

Bảng 1. Tỷ lệ trẻ có vấn đề về răng miệng thường xuyên bỏ bữa ăn (n=63)

\begin{tabular}{|c|c|c|c|c|}
\hline \multirow{2}{*}{ Bỏ biới tính } & \multicolumn{2}{|c|}{ Nam $(\mathbf{n}=\mathbf{3 5})$} & \multicolumn{2}{c|}{ Nữ $(\mathbf{n}=\mathbf{2 8})$} \\
\cline { 2 - 5 } & Số lượng & Tỷ lệ ( \%) & Số lượng & Tỳ lệ ( \%) \\
\hline Bữa sáng & 30 & 85,7 & 24 & 85,7 \\
\hline Bữa trưa & 4 & 11,4 & 3 & 10,7 \\
\hline Bữa tối & 1 & 2,9 & 1 & 3,6 \\
\hline
\end{tabular}

Có 35 học sinh nam có vấn đề về răng miệng thường xuyên bỏ ăn và 28 học sinh nữ có VĐVRM thường xuyền bỏ ăn. Trong đó tỷ lệ bỏ ăn sáng ở 2 giới đêuu là cao nhất với $85,7 \%$ ở mỗi giới.

Bảng 2. Lý do họ sinh bỏ bữa ăn $(n=63)$

\begin{tabular}{|c|c|c|c|c|}
\hline \multirow{2}{*}{ Gý doới tính bỏ bữa } & \multicolumn{2}{c|}{ Nam (n=35) } & \multicolumn{2}{c|}{ Nữ $(\mathbf{n = 2 8 )}$} \\
\cline { 2 - 5 } & Số lượng & Tỷ lệ( \%) & Số lượng & Tỷ lệ (\%) \\
\hline Không quan trọng, không thích ăn & 12 & 34,2 & 8 & 28,6 \\
\hline Không có thời gian ăn & 22 & 62,9 & 20 & 71,4 \\
\hline
\end{tabular}


VIETNAM MEDICAL JOURNAL N¹ - OCTOBER - 2021

\begin{tabular}{|c|c|c|c|c|}
\hline Bố mẹ không cho ăn & 1 & 2,9 & 0 & 0 \\
\hline \multicolumn{3}{|c|}{$\mathrm{p}>0,05$} \\
\hline
\end{tabular}

Lý do giải thích cho việc hay bỏ ăn của học sinh có VĐVRM được học sinh lựa chọn nhiều nhất là không có thời gian ăn, ở nam là $62,9 \%$ và nữ là $71,4 \%$. Tuy nhiên sự khác biệt không có ý nghĩa thống kê với $p>0,05$

Bảng 3. Tý lệ học sinh có VĐRM ăn các loại thực phẩm như bim bim, snack,... (n=115)

\begin{tabular}{|c|c|c|c|c|}
\hline \multirow{2}{*}{ Giới tính } & \multicolumn{2}{|c|}{ Nam (n=59) } & \multicolumn{2}{c|}{ Nữ (n=56) } \\
\cline { 2 - 5 } Thông tin & Số lượng & Tỹ lệ ( \%) & Số lượng & Ty̆ lệ ( \%) \\
\hline Không ăn & 4 & 6,8 & 3 & 5,4 \\
\hline Thình thoảng ăn & 52 & 88,1 & 52 & 92,9 \\
\hline Än hàng ngày & 3 & 5,1 & 1 & 1,7 \\
\hline \multicolumn{3}{|c|}{$\mathrm{p}>0,05$} \\
\hline
\end{tabular}

Tỷ lệ trẻ nữ thỉnh thoảng ăn snack, bim bim ở trẻ nữ cao hơn nam (lần lượt là 92,9\% và 88,1\%), tuy nhiển sự khác biệt không có ý nghĩa với p>0,05

Bảng 4. Tỷ lệ học sinh có VĐRM ăn đồ àn ngọt $(n=115)$

\begin{tabular}{|c|c|c|c|c|}
\hline \multirow{2}{*}{ Tân suất } & \multicolumn{2}{|c|}{ Nam (n=59) } & \multicolumn{2}{c|}{ Nữ $(\mathbf{n}=\mathbf{5 6})$} \\
\cline { 2 - 5 } & Số lượng & Tỷ lệ & Số lượng & Tỷ lệ \\
\hline Hàng ngày & 0 & 0 & 1 & 1,8 \\
\hline Thường xuyên & 9 & 15,2 & 4 & 7,1 \\
\hline Thỉnh thoảng & 45 & 76,3 & 46 & 82,2 \\
\hline Không ăn & 5 & 8,5 & 5 & 8,9 \\
\hline
\end{tabular}

Trong số nam học sinh có VĐRM có 15,2\% thường xuyên ăn đồ ăn ngọt, 76,3\% thỉnh thoảng ăn.

Tỷ lệ này ở các em nữ là $7,1 \%$ và $82,2 \%$. Tuy nhiên sự khác biệt không có ý nghĩa thống kê với $p>0,05$

Bảng 5. Thói quen uống nước có ga của học sinh ( $n=115)$

\begin{tabular}{|c|c|c|c|c|c|c|}
\hline \multirow{2}{*}{\multicolumn{2}{|c|}{ Thói quen $\quad$ Giới tính }} & \multicolumn{2}{|c|}{$\operatorname{Nam}(n=59)$} & \multicolumn{2}{|c|}{$N$ ữ $(n=56)$} & \multirow[b]{2}{*}{ p } \\
\hline & & Số lượng & Tỷ lệ (\%) & Số lương & Tỷ lê(\%) & \\
\hline \multirow{3}{*}{$\begin{array}{c}\text { Uống nước có } \\
\text { ga }\end{array}$} & Thường xuyên & 5 & 8,5 & 3 & 5,4 & \multirow{3}{*}{$>0,05$} \\
\hline & Thinh $t$ & 45 & 76,2 & 45 & 80,4 & \\
\hline & & 9 & 15,3 & 8 & 14,2 & \\
\hline \multirow{3}{*}{$\begin{array}{l}\text { Uống đồ tự pha } \\
\text { tại tiệm }\end{array}$} & Thườn & 1 & 1,7 & 2 & 3,6 & \multirow{3}{*}{$>0,05$} \\
\hline & Thinh thoảng & 33 & 55,9 & 29 & 51,8 & \\
\hline & Không uống & 25 & 42,4 & 25 & 44,6 & \\
\hline
\end{tabular}

Thói quen thỉnh thoảng uống nước có ga ở trẻ nữ (chiếm $80,4 \%$ ) cao hơn trẻ nam (chiếm $76,3 \%$ ). Thói quen thỉnh thoảng uống đồ tự pha tại tiệm ở trẻ nam cao hơn trẻ nữ là (nam $55,9 \%$ và nữ 51,8\%). Tuy nhiên sự khác biệt không có ý nghĩa thống kê với p>0,05.

\section{BÀN LUÂNN}

Trong số 324 học sinh lớp 4,5 được nghiên cứu có 115 học sinh được chẩn đoán có các bệnh lý răng miệng chiếm $35,5 \%$. Tỷ lệ này thấp hơn một số nghiên cứu của Trần Tuấn Tài ở Thừa Thiên Huế (sâu răng vĩnh viễn là $45,2 \%$ ) [4] và của Trương Mạnh Dũng ở 5 tỉnh thành của Việt Nam [5]. Trong các nghiên cứu đều chỉ ra rằng thói quen ăn uống có ảnh hưởng lớn tới tình trạng sâu răng, mảng bám, viêm lợi ở trẻ mầm non và trẻ tiểu hoc.

Ở học sinh tiểu học, những kiến thức và thái độ về bệnh răng miệng và dinh dưỡng được biểu hiện qua hành động để phòng chống nó. Dinh dưỡng cho trẻ là một yếu tố rất quan trọng để trẻ có thể phát triển cả thể chất lẫn tinh thần. Một trong những yêu cầu thiết yếu về dinh dưỡng là ăn đủ 3 bữa/ngày đối với trẻ từ 10-19 trẻ. Tuy nhiên khi được hỏi tỷ lệ trẻ không ăn 3 bữa thường xuyên chiếm tỷ lệ cao (nam 59,3\% và nữ là $50,0 \%$ ) và đa số (nam $85,7 \%$ và nữ là $85,7 \%$ ) các em bỏ bữa sáng. Theo khuyến cáo của Tố chức $Y$ tế Thế giới và Bộ $Y$ tế, bữa sáng là bữa quan trọng nhất đối với cơ thể, nó cung cấp năng lượng cho ngày dài làm việc và học tập. Nếu bỏ bữa sáng sẽ gây hậu quả khổn lường đặc biệt là trẻ em. Lý do các em đưa ra là các em không có thời gian ăn (nam là $62,9 \%$ và nữ là $71,4 \%$ ) bên cạnh đó các em cho rằng không quan trọng, không thích ăn (nam là $34,3 \%$ và nữ là $28,6 \%$ ). Ngoài các thành phố lớn Hà Nội và Thành phố Hồ Chí Minh thì đa số các tỉnh thành khác học sinh bắt đầu vào học từ 7 giờ sáng và sáng các em rất lười dậy sớm đặc biệt là mùa đông, bên cạnh đó cha mẹ các em cũng đi làm giờ đấy nên rất vội và cũng không có thời gian để ép con cái mình ăn. Hơn nữa do 
địa bàn tại thị trấn Vũ Thư những học sinh lớp 4 lớp 5 có thể tự đi đến trường và bố me sẽ cho các em tiền đến những quán ở gần trường ăn sáng nhưng rất nhiều em không ăn và dành tiền mua quá vặt. Thực phẩm các em thường ăn hàng ngày là cơm, xôi.

Nghiên cứu của Hiệp hội răng miệng Hoa kỳ trên 4000 trẻ cho thẩy trẻ bỏ bữa sang hoặc không ăn đủ hoa quả và rau trong ngày cũng tăng nguy cơ bị sâu răng ở trẻ. Báo cáo kết luận rằng thực hành ăn uống lành mạnh là một yếu tố quan trọng trong toàn bộ quá trình phức tạp dẫn đến sâu răng và các bệnh răng miệng ở trẻ [6].

Tỷ lệ học sinh trong nghiên cứu bị các bệnh răng miệng hàng ngày sử dụng bim bim, đồ ăn ngọt và uống nước có ga tương ứng là $4,7 \%$, $11,3 \%$ và $6,5 \%$. Trẻ có tiêu thụ các thực phẩm này ở mức thỉnh thoảng cũng rất cao với trên $80 \%$. Việc sử dụng các thực phẩm có nhiều đường và đồ uống có ga đã được chỉ ra là yếu tố liên quan chặt chẽ với các bệnh răng miệng. Một nghiên cứu tại Ấn Độ với 448 học sinh cũng cho thây, tiêu thụ các chất dinh dưỡng sinh nhiệt, tiêu thụ nước giải khát và các thực phẩm giàu đường/mật, cũng như sử dụng bim bim đồ ăn vặt giữa các bữa ăn có nguy cơ làm tăng các bệnh răng miệng ở trẻ [7].

\section{KẾT LUÂ̂N}

Tỷ lẹ ăn sáng hàng ngày ở học sinh có VĐVRM ở nam là $47,5 \%$ và nữ là $55,3 \%$. Có $6,5 \%$ nam và $3,6 \%$ nữ không ăn sáng. Tỷ lệ bỏ ăn sáng ở 2 giới đều là cao nhất với $85,7 \%$ ở mỗi giới.

Thói quen ăn đồ ngọt của học sinh nữ có VĐVRM cao hơn nam (lần lượt là $82,2 \%$ và
$76,3 \%)$. Ở cả 2 giới thực phẩm trẻ hay ăn vào bữa sáng là cơm, xôi lần lượt là nam 76,4\%; nữ $75,9 \%$.

\section{KHUYẾN NGH!}

Mô hình kết hợp nhà trường - gia đình cần được triển khai có hiệu quả để giáo dục các em về mối quan hệ giữa thực hành dinh dưỡng và bệnh răng miệng nhằm làm giảm tỷ lệ học sinh tiểu học mắc bệnh lý răng miệng.

\section{TÀI LIẸU THAM KHẢO}

1. Abdel Wahed Wafaa $Y$, Hassan Safaa $K$ and Eldessouki Randa (2017), "Malnutrition and Its Associated Factors among Rural School Children in Fayoum Governorate, Egypt", Journal of Environmental and Public Health, 2017, pp. 4783791.

2. Thakur. R and Gautam. RK (2016), "Coexistence of undernutrition and obesity: A cross sectional study among".

3. Psoter. W, Gebrian. B, Prophete. S, et al(2008), "Effect of early childhood malnutrition on tooth eruption in Haitian adolescents", Community dentistry and oral epidemiology, 36(2), pp. 179-189.

4. Trần Tuấn Tài. (2016). " Thực trạng bệnh sâu răng và hiệu quả của giải pháp can thiệ̂p cộng đồng của học sinh tại một số trường tiểu học ở Thửa Thiên Huế", Luần án Tiến sĩ y học, Trường Đại học Y Dược - Đại học Huế.

5. Trương Mạnh Dững, Vũ Mạnh Tuấn. (2012). Thực trạng bệnh răng miệng và một số yếu tố liên quan ở trẻ 4-8 tuổi tại 5 tỉnh thành của Việt Nam năm 2010, Tạp chí Y học thức hành, 12 (797), 56-59.

6. American Dental Association (2004). "Skipping Breakfast Ups Tooth Decay Risk For

7. V. C. Punitha, A. Amudhan (2015). Role of dietary habits and diet in caries occurrence and severity among urban adolescent school children, Journal of Pharmacy Bioallied Sciences, 7 (1), 296-300

\title{
ĐĂC ĐIỂM LÂM SÀNG VÀ CÂ̂N LÂM SÀNG ÁP XE TRUNG THẤT DO THỦNG THỰC QUẢN ĐÎ̀̂U TRI TẠI BỆNH VIỆN VIỆT ĐỨC
}

\author{
Phạm Vũ Hùng*, Nguyễn Đức Chính*, Trần Tuấn Anh*, \\ Đào Văn Hiếu*, Nguyễn Minh Ky*, Trần Tiễn Anh Phát*
}

\section{TÓM TẮT ${ }^{19}$}

Đặt vấn đề: Áp xe trung thất (AXTT) là nhiễm khuẩn nặng, nguy cơ tử vong cao, nguyên nhân do bệnh lý nhiếm khuẩn miệng, họng, đặc biệt liên quan

*Bệnh viện Việt Đức

Chịu trách nhiệm chính: Phạm Vũ Hùng

Email: hungpv5271@yahoo.com

Ngày nhận bài: 5.7.2021

Ngày phản biện khoa học: 31.8.2021

Ngày duyệt băi: 7.9.2021 đến tổn thương thực quản (TQ). Mục đích nghiên cứu chúng tôi mô tả một số đặc điểm lâm sàng và cận lâm sàng giúp cho chẩn đoán bệnh. Đối tượng và phương pháp nghiên cứu: Nghiện cứu tiến cứu các trường hợp chẩn đoán AXTT do tổn thương TQ được điều trị tại Bệnh viện Việt Đức từ 1/2016 đến 10/2019, bao gồm các trường hợp tử vong và nặng về. Chẩn đoán theo tiêu chuẩn của Estrera (1983), phân loại theo Endo S (1999). Kết quả: Tổng số có 40 trường hợp, tuổi trung bình: 48,5 $\pm 17,74$ tuổi, nam giới chiếm $82,5 \%$. Nguyên nhân tổn thương TQ do chấn thương chiếm $70 \%$, chủ yếu hóc xương; do bệnh lý 